\title{
SUGESTÕES PARA UM FUTURO CÓDIGO DE PROCESSO CIVIL
}

\author{
PROPOSALS FOR A FUTURE CODE OF CIVIL PROCEDURE
}

Eduardo Tomasevicius Filho*

\begin{abstract}
Resumo:
Nesse estudo, o autor procurou apresentar uma reflexão sobre a atividade de decisão de conflitos, a qual pouco teria mudado desde a Antiguidade, ao passo que outras atividades sociais, como a produção de bens e de serviços, teria se alterado desde a Revolução Industrial e proporcionado o desenvolvimento da administração na busca de maior eficiência produtiva. Enquanto as demais atividades procuram atender com qualidade, confiabilidade e rapidez às necessidades sociais contemporâneas, aplicando-se conceitos da administração, a atividade judiciária ainda mantém componentes de sociedades pré-industriais, o que gera a crise do Poder Judiciário em termos de demora excessiva dos processos e insatisfação generalizada da população. Para tanto, fez-se revisão da literatura processualística, apresentaram-se as ideias fundamentais da ciência da administração, analisou-se o Poder Judiciário do ponto de vista dessa ciência e propuseram-se, ao final, sugestões para futuras reformas do Direito Processual Civil.

Palavras-chave: Novo Código de Processo Civil. Poder Judiciário. Lentidão das decisões judiciais. Teoria da Administração. Reforma do Direito Processual Civil.
\end{abstract}

\begin{abstract}
:
In this paper, the author presented a reflection on settlement of disputes, which had not substantially changed along the time, whereas other social activities, such as the production of goods and services, have been modified since the Industrial Revolution and caused the development of management for a greater productive efficiency. Though other activities try to reach quality, reliability and speed for the fulfillment of needs in a contemporary society, by the accomplishment of management, the judicial activity still retains features of pre-industrial societies, which leads to a judicial crisis in terms of excessive delay in the lawsuits and general dissatisfaction of the population. The author reviewed the literature, presented fundamental ideas of management, analyzed the judicial power from a managerial point of view and proposed suggestions for forthcoming reforms in the civil procedural law.
\end{abstract}

Keywords: The new Civil Procedure Code. Judicial power. Delay in lawsuits. Management. Reform of Civil Procedure Law.

* Professor Doutor do Departamento de Direito Civil da Faculdade de Direito da Universidade de São Paulo. E-mail: tomasevicius@usp.br. 
1. Introdução

Em 16 de março de 2015, promulgou-se um novo Código de Processo Civil no Brasil. Esse novo texto legal é importante mudança de paradigma no direito processual brasileiro, porque se encerrou um ciclo virtuoso iniciado muito tempo atrás, com o pioneirismo de grandes professores de direito processual, notadamente, aqueles que lecionaram nas Arcadas e que deram origem à "Escola de São Paulo", cujo baluarte foi o Código de Processo Civil de 1973. Nos últimos quarenta anos, diversos professores das "Arcadas" e também de outras Casas levaram adiante, com brilhantismo, os valores dessa escola de pensamento jurídico. Pode-se dizer, inclusive, que se formou uma "Escola Processual Brasileira". ${ }^{1}$ Com o novo Código de Processo Civil, inicia-se, agora, um novo ciclo, no qual se busca não apenas a adequação do texto legal ao estado da arte em termos doutrinários, jurisprudenciais e legislativos, mas também a adoção de novos princípios e valores, entre os quais a boa-fé e a cooperação processuais, além de novas técnicas de aceleração da marcha do processo.

Nesse contexto de mudanças legislativas e de debates doutrinários sobre o novo Código de Processo Civil, também gostaria de oferecer minha opinião sobre o tema, a partir de um paradigma extrajurídico, que é o da administração. Com efeito, a proposta desse texto é a de usar ideias desta área do conhecimento como exercício de interdisciplinaridade entre o direito e áreas afins das ciências sociais aplicadas, de modo que, eventualmente, algumas delas possam ser aproveitadas em futuras reformas do direito processual.

\section{A solução de conflitos como técnica ou arte}

Um dos brocardos mais conhecidos dos juristas é o "ubi societas ibi ius", isto é, onde houver sociedade, haverá direito. Divergências de percepção e de opinião e a disputa por certa e determinada coisa, geram conflitos e estes precisam ser solucionados, preferencialmente, pelo direito, em vez do uso da força, entendida como vingança privada individual ou coletiva. Naturalmente, atribuíram-se a certos membros de cada sociedade a função de solução de conflitos. Em algumas delas, pouco complexas, essa tarefa coube ao rei, aos sacerdotes religiosos ou a pessoas honradas da comunidade. Em outras sociedades mais complexas, essa atividade foi desempenhada por juízes especializados nessa tarefa.

Exemplo dessa transformação está no próprio Direito Romano, que, ao longo de mil anos, teve seus conflitos julgados pelo "Rex"; depois assistiu à criação

GABBAY, Daniela Monteiro et al. Cândido Rangel Dinamarco e a instrumentalidade do processo (uma entrevista). Cadernos Direito GV. São Paulo: Direito GV, v. 7, n. 4, p. 1-41, jul. 2010. p. 17. 
do sistema da "ordo iudiciorum privatorum", em que o pretor, magistrado responsável, entre outras questões, pela administração da justiça, preparava a lide para ser decidida por um cidadão honrado, o "Iudex". Nas últimas fases do Império Romano, os conflitos passaram a ser solucionados também por um "Iudex", mas este se tornara um magistrado especializado nessa atividade. ${ }^{2}$ Com a oficialização do cristianismo como religião oficial, os bispos também solucionavam conflitos interpessoais a eles submetidos na audientia episcopalis. ${ }^{3}$

Encontram-se nas fontes romanas ${ }^{4}$ outros tantos brocardos sobre a maneira pela qual se deveriam julgar os litígios, muito provavelmente formulados a partir da experiência prática, como lições tiradas de equívocos e de injustiças ocorridas em diversos casos concretos. Destacam-se: "O juiz deve ter a equidade diante dos olhos"; " $\mathrm{O}$ juiz deve proferir a sentença conforme ditar sua consciência”, ${ }^{6}$ ou, em sentido contrário, "O juiz deve julgar segundo o alegado e provado e não conforme a própria consciência"; 7 "É criminosa a pressa em julgar", " $\mathrm{Na}$ dúvida, é preferível favorecer ao réu do que ao autor", 9 "O juiz terá desempenhado sua função, julgando bem ou mal"10 e o "Não há quem ignore que seja frequente e necessário o uso da apelação, porque esta corrige a injustiça e a ignorância dos juízes, posto que algumas vezes reforme para pior as sentenças bem proferidas; porque nem sempre julga melhor aquele que por último teve de proferir a sentença". ${ }^{11}$

Ao longo da Idade Média, acrescentaram-se novas ideias aos procedimentos de solução de controvérsias, sendo que a maior parte delas teve origem no Direito Canônico. Tornaram-se princípios fundamentais do direito processual contemporâneo a ampla defesa, os libelos por escrito, assistência jurídica gratuita, o fim de provas irracionais e o devido processo legal.

Dessa forma, o julgamento de conflitos nasceu e desenvolveu-se como uma técnica (do grego techne) ou arte (do latim ars), palavras sinônimas no mundo antigo

2 ALVES, José Carlos Moreira. Direito romano. 14. ed. rev., corrigida e aum. Rio de Janeiro: Forense, 2007. p. 203-268.

3 TUCCI, José Rogério Cruz e; AZEVEDO, Luiz Carlos de. Lições de processo civil canônico: história e direito vigente. São Paulo: Revista dos Tribunais, 2001. p. 20.

4 Cf. VELLOSO, Augusto Versiani. Textos de direito romano. Bello Horizonte: Imprensa Official de Minas, 1923. p. $21,98,130$ e 221.

5 "Aequitatem ante oculos habere debet iudex".

6 "Iudex prout religio suggerit, sententiam profere debet".

7 "Iudex secundum allegata et probata, non autem secundum propriam conscientizam iudicare debet".

8 "In iudicando criminosa est celeritas".

9 "Reo favere in dubio est potius quam auctori".

10 "Male seu bene iudicaverit, officio functus est".

11 "Appelandi usus quam sit frequens, quamque necessarius, nemo est, qui nesciat: quippe cum iniquitatem iudicantum, vel imperitiam corrigat, licet non nunquam bene latas sententias in pejus reformet: neque enim utique melius pronuntiat, qui novissimus sententiam laturus est". 
e, por isso, guarda muitos pontos de contato com as demais artes. Assim como o artista plástico se isola para pintar um quadro e o escultor se fecha no canteiro para fazer uma escultura, o juiz também fica isolado, concluso, em seu gabinete, para a produção de uma decisão para um conflito que lhe foi submetido para análise. A sentença é a sua obra de arte e a beleza desta está no maior ou menor grau de justiça, que é, na verdade, o aspecto estético da decisão judicial. Todos admiram a decisão justa, como se admira a beleza de um quadro, de uma escultura ou de um edifício bem arquitetado.

Os demais objetos também eram produzidos dessa maneira até a Idade Moderna. Os artesãos, unidos por meio da corporação de ofício, que estabelecia o monopólio do exercício da atividade, ${ }^{12}$ tinham suas próprias ferramentas, usavam suas próprias matérias-primas e os produtos, manufaturados em pouca quantidade, eram vendidos no mercado local. Tudo era concentrado na pessoa do mestre-artesão, porque ele não apenas fabricava os produtos, como também comprava as matérias-primas, administrava os jornaleiros e aprendizes sob seu comando e atendia aos clientes ao vender o que havia produzido. ${ }^{13}$ Porém, a partir do século XVIII, com o desenvolvimento das ciências exatas, o mundo conheceu a denominada "Revolução Industrial", a qual provocou uma crise gerada pela dissociação entre a estrutura tradicional de sociedade ocidental e os novos modos de produção. Desde então, objetos passaram a ser fabricados de acordo com esses novos conhecimentos e com maior racionalização do trabalho devido ao uso das máquinas que não usavam força humana ou animal, como, por exemplo, aquelas que tinham motor a vapor, o que aumentou significativamente a produção desses bens. Embora se tenha discutido por muito tempo a conveniência ou não de fabricarem-se produtos em grande quantidade, o resultado final foi a ampliação sem precedentes do atendimento das necessidades das pessoas.

Por outro lado, a produção de decisões judiciais das sociedades atuais, de massas, complexas e de risco, ainda está baseada, em grande parte, na antiga estrutura artesanal, tradicional, do Estado-juiz como única forma visível da presença do rei na comunidade, portanto, anterior à Revolução Industrial. Em linhas gerais, o modelo consagrado de solução de controvérsias continua estruturado no juiz isolado, que analisa cada caso individualmente, um após o outro. Por ser uma arte cuja beleza é a justiça, leva-se o tempo que for preciso para o término da obra, consubstanciada na sentença ou no acórdão: afinal, o tempo do processo é distinto do tempo cronológico. Devido à falibilidade do julgador, deve-se sempre assegurar uma nova oportunidade para revisão da decisão judicial, para que esta seja corrigida e aperfeiçoada, o que exige a estruturação

\footnotetext{
12 HUBERMAN, Leo. História da riqueza do homem. Tradução de Valtensir Dutra. 21. ed. Rio de Janeiro: Guanabara-Koogan, 1986. p. 55.

13 Id. Ibid., p. 110.
} 
do sistema por meio da hierarquia entre juízes, iniciando-se a apreciação dos casos, na quase totalidade deles, por um magistrado hierarquicamente inferior, que terá seu trabalho revisado, corrigido, aprimorado ou invalidado por um magistrado de hierarquia superior.

Essa situação gera muitos problemas para a sociedade, entre os quais a enorme quantidade de ações em tramitação no Poder Judiciário não julgadas em curto espaço de tempo. Pela demora, tornam-se injustas - "justiça atrasada não é justiça, senão injustiça qualificada e manifesta"14 - ou até mesmo ineficazes, gerando a situação de "ganhar, mas não levar".

Há bastante tempo, essa situação causa desconforto entre os processualistas. Destacam-se Piero Calamandrei, ${ }^{15}$ que apresentou uma sátira do Poder Judiciário italiano, como também Mauro Capelletti e Bryant Gardth, ${ }^{16}$ na década de 1970, quando trataram de problemas em parte existentes até os dias atuais, como a necessidade do aperfeiçoamento da assistência jurídica gratuita, dos juizados de pequenas causas e das justiças especializadas, a proteção dos interesses difusos, a distinção entre litigantes habituais dos litigantes eventuais, além da necessidade de desafogamento do Poder Judiciário mediante uso de arbitragem e conciliação.

No Brasil, essa preocupação é recorrente, exteriorizada pela elaboração de dissertações e teses sobre o tema. A mais famosa delas, e que gerou resultados positivos concretos, é a de Cândido Rangel Dinamarco sobre a instrumentalidade do processo. Nessa obra, ele propôs uma revisão do direito processual, para que este pudesse se distanciar do formalismo e do isolamento, com o intuito de alcançar-se maior efetividade, até pelo fato de que a legitimidade do Poder Judiciário estaria arranhada pela crônica demora e custos elevados. ${ }^{17}$ Para isso, desejava que se formasse uma nova mentalidade entre os cultores do processo, ${ }^{18}$ um novo método de pensamento do processualista e do profissional do foro. ${ }^{19}$ Para isso, Dinamarco elencou escopos do processo, como o escopo social de pacificação e educação da população para o exercício de seus direitos e obrigações $;{ }^{20}$ o escopo político, de zelar pela capacidade estatal de decidir imperativamente os conflitos, concretizar o valor da liberdade e assegurar a participação dos cidadãos nos destinos da sociedade, ${ }^{21} \mathrm{e}$

14 BARBOSA, Rui. Oração aos moços. 8. ed. Rio de Janeiro: Ediouro, 1997. p. 74.

15 CALAMANDREI, Piero. Eles, os juizes, vistos por nós, os advogados. Tradução de Ari dos Santos. Lisboa: Clássica, 1940.

16 CAPPELLETTI, Mauro; GARTH, Bryant. Acesso à justiça. Tradução e revisão de Ellen Gracie Northfleet. Porto Alegre: Fabris, 1988.

17 DINAMARCO, Cândido Rangel. A instrumentalidade do processo. São Paulo: Revista dos Tribunais, 1987. p. 446.

18 Id. Ibid., p. 9-10.

19 Id. Ibid., p. 435.

20 Id. Ibid., p. 221-224.

21 Id. Ibid., p. 233-234. 
o escopo jurídico, que é a própria aplicação do direito ou fazer valer a vontade concreta do direito. ${ }^{22}$

Outro exemplo é o trabalho de José Rogério Cruz e Tucci ${ }^{23}$ sobre o tempo do processo, no qual se procurou evidenciar o drama causado às partes pela excessiva lentidão no oferecimento de uma decisão judicial, destacando, ainda, o reconhecimento do prazo razoável para o desenvolvimento do processo como direito fundamental, ${ }^{24}$ e indicando mecanismos de aceleração do processo, como a tutela antecipada, o procedimento monitório e as ações coletivas.

Oreste Nestor de Souza Laspro analisou o duplo grau de jurisdição, apontando que este foi usado em diversos períodos da história como meio de concentração de poder. Não é um princípio expressamente previsto na Constituição Federal e, a despeito de a recorribilidade das decisões permitir a revisão por um colegiado de magistrados mais experientes, por outro lado, essa possibilidade leva ao desprestígio das instâncias inferiores e à demora da prestação jurisdicional. ${ }^{25}$

Também merece destaque Rodolfo de Camargo Mancuso, ${ }^{26}$ que tratou do problema do monopólio estatal dos conflitos e o consequente deficit de confiabilidade social no serviço judiciário estatal, somadas as dificuldades nas soluções de megaconflitos, a coletivização dos processos, bem como os problemas na excessiva duração dos processos e também dos elementos de contenção recursais. Simultaneamente, Antonio Carlos Marcato ${ }^{27}$ apresentou reflexões sobre o uso de precedentes, decisões e súmulas vinculantes, além de súmulas impeditivas de recursos e julgamentos de plano de causas repetitivas como meios de correção do problema da demora dos processos judiciais. Esse autor, inclusive, ressaltou que não se trata de um problema exclusivamente brasileiro, mas também existente na maior parte dos países.

Nos últimos anos na pós-graduação da Faculdade de Direito da USP, por exemplo, foram realizadas diversas pesquisas, sob a forma de dissertações de mestrado e

22 DINAMARCO, Cândido Rangel. A instrumentalidade do processo. São Paulo: Revista dos Tribunais, 1987. p. 247-447.

23 TUCCI, José Rogério Cruz e. Tempo e processo: uma análise empírica das repercussões do tempo na fenomenologia processual: civil e penal. São Paulo: Revista dos Tribunais, 1997.

24 A Emenda Constitucional n. 45, de 2004, inseriu o inciso LXXVII ao art. $5^{\circ}$ da Constituição Federal com a seguinte redação: "a todos, no âmbito judicial e administrativo, são assegurados a razoável duração do processo e os meios que garantam a celeridade de sua tramitação".

25 LASPRO, Oreste Nestor de Souza. Duplo grau de jurisdição no direito processual civil. São Paulo: Revista dos Tribunais, 1995.

26 MANCUSO, Rodolfo de Camargo. A resolução dos conflitos e a função judicial no contemporâneo Estado de Direito. 2008. Tese (Professor Titular) - Faculdade de Direito, Universidade de São Paulo, São Paulo, 2008.

27 MARCATO, Antonio Carlos. Crise da justiça e influência dos precedentes judiciais no direito processual civil brasileiro. 2008. Tese (Professor Titular) - Faculdade de Direito, Universidade de São Paulo, São Paulo, 2008. 
teses de doutorado acerca do tratamento coletivo de interesses individuais homogêneos, técnicas de agregação de demandas repetitivas, uso de precedentes judiciais e duração razoável do processo. A grande quantidade de trabalhos impede de comentá-los de forma individualizada. Do mesmo modo, esses temas são recorrentes nas centenas de artigos de periódicos, que, em geral, repetem os mesmos argumentos trazidos nos importantes textos de direito processual civil.

Nos cursos jurídicos, estuda-se como criar e aplicar o direito, mas não se ensina como organizar o trabalho humano. No máximo, a reflexão sobre a prática jurídica é realizada pela sociologia do direito, que aponta a existência de crises das carreiras jurídicas e da efetividade do direito. A despeito de suas peculiaridades, a atividade judiciária, do ponto de vista de sua organização, é similar às atividades de outras instituições sociais, sejam elas lucrativas ou não. Com efeito, não há muita diferença entre a atividade de administração dos conflitos sociais realizada pelo Poder Judiciário, das atividades de uma fábrica, de um hospital, de uma loja ou hotel pertencentes a uma rede ou de uma companhia aérea. Se estas atividades se aperfeiçoaram a ponto de não se admitirem mais atrasos de minutos ou a prestação de serviços de baixa qualidade, o mesmo poderia acontecer com o Poder Judiciário. Do ponto de vista histórico, foi na indústria que se iniciou a análise científica da atividade em si mesma por ela desempenhada, o que levou ao desenvolvimento da administração para o aprimoramento da produção. Convém conhecer, ao menos, os pensamentos dos principais expoentes desse ramo do conhecimento, para que se possa compreender por que essas atividades humanas passaram a ser realizadas com mais eficiência.

3. As transformações do trabalho na Idade Contemporânea: a administração da produção

a) Os primórdios da administração e a "Escola Clássica"

A administração é o ramo do conhecimento humano que tem por objetivo a melhoria do desempenho das organizações. ${ }^{28}$ Esse conhecimento não se limita à administração das empresas, mas a toda e qualquer instituição, independentemente de ter ou não fim lucrativo. ${ }^{29}$ Preliminarmente, devem-se evitar certos estereótipos, por exemplo, o de concebê-la como um meio de exploração do empregador pelo empregado, como forma de maximização de lucros ou de desumanização das relações sociais, ou,

28 MAXIMIANO, Antonio Cesar Amaru. Introdução à administração. 7. ed. rev. e ampl. São Paulo: Atlas, 2008. p. 3-4.

29 CHIAVENATO, Idalberto. Teoria geral da administração. Abordagens prescritivas e normativas da administração. 6. ed. rev. e atual., 13. tir. Rio de Janeiro: Elsevier, 2001. v. 1. p. 1. 
ainda, que esta é somente compatível com o setor privado, isso sem falar do uso pejorativo dos termos "Taylorismo", "Fordismo" e "Toyotismo", empregados indiscriminadamente por diversos cientistas sociais que nunca leram esses autores.

Da Antiguidade vieram dois exemplos de instituições que só se mantiveram por causa da administração: o exército e a Igreja. Para que estas tivessem estabilidade, foi preciso pensar em liderança, estratégia, suprimentos, divisão de tarefas, controle de finanças, entre outros fatores. Na Baixa Idade Média, a administração precisou ser novamente implantada nas atividades comerciais, porque as companhias necessitavam organizar-se com racionalidade. ${ }^{30}$

No século XVIII, quando o sistema mercantilista foi substituído pelo sistema liberal, os processos de produção sofreram importantes transformações com a substituição de manufaturas por fábricas. Nestas últimas, aliás, implantou-se racionalmente a divisão do trabalho. Em 1776, Adam Smith iniciou seu livro “A riqueza das nações”, sustentando os benefícios da divisão do trabalho e ilustrando esse fato a partir da fabricação de alfinetes. ${ }^{31}$ Nesse exemplo, Smith apontou que, na fabricação artesanal desse produto, cada trabalhador levaria um dia inteiro para fazer uma unidade. Porém, se o trabalho desses operários fosse dividido de forma especializada, de tal sorte que um deles fosse encarregado de transportar o fio, outro de endireitá-lo, um terceiro de cortá-lo, um quarto de afinar uma das extremidades, um quinto de colocar a cabeça na outra extremidade e um sexto de dar o acabamento final e um sétimo de guardá-los nas embalagens, o resultado final seria muito mais eficiente. Em uma oficina visitada por Smith, em que se aplicava a divisão do trabalho, dez operários fabricavam quarenta e oito mil alfinetes por dia. Fazendo-se a média aritmética simples, cada trabalhador fabricava quatro mil e oitocentos alfinetes por dia. Entretanto, se não houvesse a divisão do trabalho, cada trabalhador fabricaria apenas um alfinete por dia.

Já no início do século XX, quando já estava praticamente consolidada a fase do capitalismo industrial, a organização do trabalho tornou-se científica. Nessa época, o grande problema existente era a luta de classes, em que os patrões exploravam os trabalhadores com baixos salários, péssimas condições de trabalho, ausência de instrução e manipulação dos relógios de ponto. Os empregados defendiam-se como podiam, inclusive levando o máximo de tempo possível para o término do trabalho. Portanto, o produto final da atividade industrial era ineficaz.

30 CHIAVENATO, Idalberto. Teoria geral da administração. Abordagens prescritivas e normativas da administração. 6. ed. rev. e atual., 13. tir. Rio de Janeiro: Elsevier, 2001. v. 1.

31 SMITH, Adam. Investigação sobre a natureza e as causas da riqueza das nações. Tradução de Conceição Jardim Maria do Carmo Cary e Eduardo Lucio Nogueira. São Paulo: Abril Cultural, 1974. (Os Pensadores). p. 13-14. 
Nesse contexto, surgiram pensadores que se tornaram os precursores de uma ciência da administração, reunidos pela literatura como pertencentes à "Escola Clássica" da administração. O primeiro deles é Frederick Winslow Taylor, que iniciou o curso de direito em Harvard, mas acabou desistindo dessa carreira ao ter optado pela engenharia mecânica. Em um de seus livros, intitulado "Princípios de Administração Científica", ele apontou que os interesses entre patrões e empregados eram antagônicos: aqueles pagavam salários cada vez menores e, em contrapartida, estes procuravam trabalhar o menos possível, "fazendo cera" a maior parte do dia. ${ }^{32}$ Como agravante, quem se esforçava para trabalhar, acabava desanimando, ao constatar que os colegas que só "enrolavam", ganhavam os mesmos salários. Ele destacou a denominada "indolência sistemática": intimidava-se e ameaçava-se quem queria trabalhar normalmente. Como consequência desse círculo vicioso, a "cera" estava disseminada pelas fábricas. ${ }^{33}$

Taylor observou que as técnicas de trabalho se mantinham pela tradição oral e a organização dos trabalhos, ainda que dividida, era precária, resultando em enormes desperdícios de energia das pessoas, por submetê-las desnecessariamente à fadiga. Com efeito, não se sabia ao certo o que realmente consistia um dia de trabalho de uma pessoa. O exemplo dado foi o de um pedreiro, cujo corpo pesava $75 \mathrm{~kg}$, e que precisava deslocar seu corpo por $60 \mathrm{~cm}$ cerca de mil vezes por dia. Até aquele momento, ninguém havia analisado pormenorizadamente os movimentos desse trabalhador. Porém, ele defendeu a análise racional dessa atividade, para averiguar quais passos podiam ser eliminados ou melhorados em termos de posição da pá e do balde de argamassa. Observou-se que eles podiam ser reduzidos de dezoito para cinco, com supressão de certos movimentos que se acreditavam necessários, mas que, por análise, se revelavam inúteis, bem como a introdução de dispositivos simples, que eliminavam movimentos fatigantes e demorados, e a melhor posição para as mãos. ${ }^{34}$

A partir de um exemplo simples como este, Taylor trouxe para a administração o problema dos efeitos deletérios da fadiga do trabalhador pela realização inadequada das atividades desempenhadas. Para tanto, ele cronometrava o tempo gasto em cada parada provocada desnecessariamente pela fadiga, e sugeriu um sistema de incentivos: quanto mais o trabalhador fosse produtivo, maior deveria ser o seu salário e, sobretudo, que o patrão cumprisse essa promessa. Por ser empregado de fábrica, Taylor relatou que fora ameaçado de morte por seus colegas, para que abandonasse essas ideias. Em sua opinião, não deveria haver uma luta de classes, mas, sim, o reconhecimento de

32 TAYLOR, Frederick Winslow. Princípios de administração científica. 7. ed. Tradução de Arlindo Vieira Ramos. São Paulo: Atlas, 1970. p. 30-32.

33 Id. Ibid., p. 37.

34 Id. Ibid., p. 78-80. 
que tanto patrões quanto empregados tinham os mesmos interesses em comum, que é o de ambos serem igualmente prósperos: "Parece tão evidente por si mesmo o princípio que a máxima prosperidade para o patrão acompanhada da máxima prosperidade para o empregado devem ser os dois fins principais da administração, que seria desnecessário demonstrá-lo". ${ }^{35}$ Inclusive ele propunha a participação dos empregados nos lucros das empresas como forma de estímulo à produtividade.

Henry Ford, embora fosse conhecedor do pensamento de Taylor, desenvolveu métodos próprios de produção e acabou se tornando conhecido por ter desenvolvido o conceito de estandardização para produção em massa. Tornou-se conhecida a ideia de fabricação de um único modelo de automóvel da mesma cor, concentrando-se todos os esforços em um produto único, em vez de diversificá-los, perdendo-se o foco, para que se conseguisse oferecer o melhor produto, que melhor atendesse aos desejos e necessidades do mercado, pelo menor preço, por meio de contínua pesquisa para proporcionar o emprego das melhores técnicas possíveis no momento. ${ }^{36}$ Dessa forma, a produção em grande escala resultava na redução dos custos de produção. No entanto, dever-se-ia ter cuidado com o uso de "standards" de produção, porque:

Em matéria de standard há que ir devagar, pois que é muito mais fácil fixar um standard errado do que um certo. Certas estandardizações marcam apenas inércia; outras, progresso. Daí o perigo de falar ligeiramente a respeito. ${ }^{37}$

Ademais, Ford descreveu a necessidade de melhoria das condições de trabalho dos operários para aumento da produtividade. No entanto, em certa passagem, ele afirmou que a monotonia do trabalho não causasse mal ao funcionário. Também apontou a necessidade de treinamento dos funcionários, o que ensejaria até mesmo a reforma do sistema de ensino, para que fosse mais prático e interessante às crianças, bem como a melhoria das boas condições de trabalho, o pagamento de bons salários, a participação nos lucros, a simplificação dos processos nas linhas de produção, a melhoria dos canais de distribuição e de logística, a organização dos sistemas ferroviários para barateamento dos custos de produção, a fácil disponibilização de peças no mercado para conserto dos veículos (entendido atualmente como "pós-venda"), e a economia de matérias-primas nos processos de fabricação. ${ }^{38}$ Por exemplo, quanto mais pesado fosse o carro, mais combustível consome apenas para se arrastar e mais matéria-prima usava. Quanto mais

\footnotetext{
35 TAYLOR, Frederick Winslow. Princípios de administração científica. 7. ed. Tradução de Arlindo Vieira Ramos. São Paulo: Atlas, 1970. p. 29.

36 FORD, Henry. Os princípios da prosperidade. Tradução de Monteiro Lobato. 3. ed. São Paulo: Freitas Bastos, 1967. p. 44 e 252.

37 Id. Ibid., p. 251.

38 Id. Ibid., p. 37, 81, 85, 88, 89, 105, 110 e 159.
} 
leve o carro, menos combustível usaria e, consequentemente, menos matérias-primas usaria. $^{39}$

Outro grande autor clássico da administração foi Henry Fayol, engenheiro francês que organizou teoricamente os conceitos básicos da administração. São dele as noções mais generalizadas sobre essa matéria. No início de seu texto intitulado “Administração Industrial e Geral", ele sistematizou as seis operações de toda empresa. As cinco primeiras operações seriam: a) operações técnicas, de produção, fabricação e transformação; b) operações comerciais, de compras e vendas; c) operações financeiras, de procura e gerência de capitais; d) operações de segurança, de proteção de bens e de pessoas; e) operações contábeis, de inventários, balanços, preços e estatísticas. A sexta operação era a administrativa, que se voltava às cinco operações básicas anteriores. Dessa maneira, administrar resumir-se-ia a prever, organizar, comandar, coordenar e controlar. ${ }^{40}$ Quando uma dessas operações vai mal, a empresa pode enfraquecer ou fechar.

Fayol elencou os denominados "princípios da administração", que, em linhas gerais, embora com variantes, se mantêm até os dias atuais. São eles: a) divisão do trabalho; b) autoridade e responsabilidade; c) disciplina; d) unidade de comando; e) unidade de direção; f) subordinação do interesse particular ao interesse geral; g) remuneração do pessoal; h) centralização; i) hierarquia; j) ordem; k) equidade; 1) estabilidade do pessoal; m) iniciativa; n) união do pessoal. ${ }^{41}$

Max Weber também analisou o problema da administração, quando apresentou uma reflexão crítica acerca da sociedade, ao ter analisado os tipos de dominação, que, segundo o próprio autor, consistem na probabilidade de encontrar obediência dentro de um grupo. Para esse autor, haveria três tipos básicos de dominação: tradicional, carismática e legal. Nesse texto será analisada apenas esta última.

A dominação legal, ${ }^{42}$ que seria de natureza racional, assenta-se em regras abstratas e fixas, em vez de obedecer-se a determinada pessoa. A autoridade, também entendida por magistratura, por sua vez, é escolhida em razão de sua formação profissional por meio de concurso e o cargo não lhe pertencerá. O exercício do cargo é a única profissão do funcionário - para que este se dedique integralmente às suas atividades mediante remuneração, em vez da honra do exercício do mesmo - e sua ascensão se dará

39 FORD, Henry. Os princípios da prosperidade. Tradução de Monteiro Lobato. 3. ed. São Paulo: Freitas Bastos, 1967. p. 58.

40 FAYOL, Henri. Administração industrial e geral. Tradução de Irene de Bojano e Mário de Souza. 9. ed. São Paulo: Atlas, 1977. p. 17-28.

41 Id. Ibid., p. 34.

42 WEBER, Max. Economía y sociedad: esbozo de sociología comprensiva. Tradução de José Medina Echavarria, Juan Roura Parella, Eugenio Imaz, Eduardo Garcia Maynes e José Ferrater Mora. Cidade do México: Fondo de Cultura Económica, 1992. p. 716-752. 
ao longo da carreira profissional, pelos anos de exercício ou por serviços prestados, a critério das autoridades superiores. A ela serão outorgadas, dentro de uma competência limitada, objetiva e previamente definida, as funções, os deveres, os poderes necessários e os meios coativos para forçar o cumprimento das ordens. Autoridades hierarquicamente superiores regulam e inspecionam as atividades das autoridades de hierarquia inferior, submetendo-os à rigorosa disciplina e vigilância administrativa. $\mathrm{O}$ trabalho deve ater-se ao que está registrado no documento (expediente) e as ordens devem, preferencialmente, ser transmitidas por escrito. Dessa maneira: "O expediente e a atividade continuada pelo funcionário fazem com que o escritório seja a medula de toda forma moderna na atividade das associações". ${ }^{43}$

As vantagens de adotar-se a burocracia como forma de dominação, segundo Weber, estariam no seu aspecto racional, por proporcionar precisão, continuidade, disciplina, rigor e confiança, sobretudo, por conferir estabilidade, porque: "A burocracia continua funcionando mesmo durante a revolução triunfante ou durante a ocupação do inimigo, mesmo que não haja governo nesse momento". ${ }^{44}$ Por outro lado, a burocracia tende a ser um fim em si mesmo, pois restaria saber quem controla o aparato burocrático existente, uma vez que esse se mantém até mesmo sem comando.

b) A "Escola Neoclássica" e o "Sistema Toyota de Produção"

O grande autor neoclássico da administração é Peter Drucker. Nascido na Áustria em 1909, formou-se em direito naquele país e obteve o título de doutor em direito público e internacional pela Universidade de Frankfurt. Com o advento do nazismo, emigrou aos Estados Unidos e tornou-se professor de administração da Universidade de Nova Iorque e consultor de diversas empresas, tendo auxiliado na grande reorganização da General Motors. ${ }^{45}$

Embora tenha escrito até o limiar do século XXI, de modo a tratar dos desafios dos tempos recentes, algumas ideias importantes de Drucker foram produzidas na década de 1950, no contexto do pós-guerra e a ascensão do "Novo Estado Industrial". Em seu livro intitulado "Prática da Administração de Empresas", de 1955, estão alinhavadas as características gerais da administração contemporânea. A primeira delas é que a administração deve ser profissional e coletiva, e não mais uma administração fortemente centralizada, tal como aconteceu com a Ford, que entrou em declínio pelo fato de Henry

43 WEBER, Max. Economía y sociedad: esbozo de sociología comprensiva. Tradução de José Medina Echavarria, Juan Roura Parella, Eugenio Imaz, Eduardo Garcia Maynes e José Ferrater Mora. Cidade do México: Fondo de Cultura Económica, 1992. p. 175.

44 Id. Ibid., p. 178.

45 LODI, João Bosco. Introdução à Obra de Peter F. Drucker. RAE-Revista de Administração de Empresas, São Paulo, v. 8, n. 29, p. 80-137, out./dez., 1968. p. 83. 
Ford, dono da companhia, ser o único responsável pela tomada de decisões, dispensando, inclusive, aqueles que eram contrários a ele. ${ }^{46}$ Dessa maneira, Drucker defendia uma administração funcional. O segundo ponto destacado é que as empresas devem ter como função primordial o bom desempenho econômico, porque:

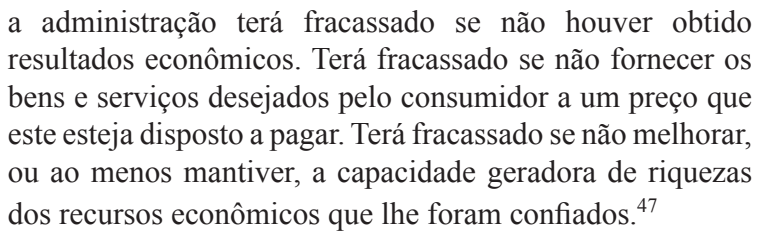

O uso inadequado do sistema de linha de produção, em que cada pessoa realizava um movimento, também foi criticado por Drucker, ao colocar o problema da dificuldade de saber como organizar o trabalho humano. Ele propôs aprimoramentos nesse sistema, como o critério da integração das atividades, em vez de atribuir-lhe a realização de determinado ato em uma linha de produção, para que se pudesse aproveitar melhor a capacidade do ser humano de criar, julgar, planejar e modificar, ${ }^{48}$ deixando-se as tarefas essencialmente mecânicas às máquinas.

Drucker é bastante conhecido por ter sido o grande divulgador da ideia da administração por objetivos, que consiste no estabelecimento dos resultados almejados. Uma vez definidos, competem aos administradores escolher as estratégias por meio do equilíbrio entre necessidades e possibilidades, comunicá-las aos funcionários com clareza, motivá-los corretamente, por meio de incentivos e promoções e, ao final, realizar a avaliação por meio de critérios claros. Por fim, pelo fato de Drucker ser preocupado com a profissionalização e contrário à administração familiar, cujas decisões são tomadas por impulsos, e consciente de que, em última análise, administrar uma empresa é administrar pessoas de forma respeitosa, ele destacou que o administrador tem o dever de formar as pessoas que trabalham na empresa, como também a si próprio. ${ }^{49}$

Para Drucker: "a maior vantagem da administração por objetivos talvez resida no fato de que ela permite que os dirigentes controlem o próprio desempenho. No autocontrole, há uma motivação mais poderosa: o desejo de fazer o melhor possível e não apenas o suficiente para "ir levando". ${ }^{50}$ Consequentemente, existiriam três dimensões na administração:

46 DRUCKER, Peter Ferdinand. Prática da administração de empresas. Tradução de Carlos A. Malferrari. São Paulo: Thomson Pioneira, 1981. p. 107.

$47 \quad$ Id. Ibid., p. 8.

48 Id. Ibid., p. 278-279.

49 Id. Ibid., p. 325-326.

50 DRUCKER, Peter Ferdinand. Introdução à administração. Tradução de Carlos A. Malferrari. São Paulo: Thomson Pioneira, 1984. p. 433. 
meditar demoradamente na finalidade e missão específicas da entidade (trate-se de empresa privada, de hospital ou de universidade) e especificá-las; fazer com que o trabalho seja produtivo e o trabalhador se realize; conduzir as repercussões sociais e as responsabilidades sociais da organização. ${ }^{51}$

Contudo, a administração por objetivos tem sido bastante criticada, mais por ser mal compreendida do que por ser inadequada. Isso porque nem sempre se estabelecem corretamente os objetivos, a comunicação entre os administradores e os subordinados tem sido precária, não se busca constantemente a inovação, e enfatiza-se sobremaneira o resultado a qualquer custo, a partir de números arbitrários, punindo-se quem não consegue atingi-los.

Na década de 1950, o Japão precisou reorganizar sua indústria por meio do aprimoramento dos conceitos tradicionais da administração da produção. $O$ norteamericano W. Edwards Deming disseminou entre engenheiros japoneses a ideia de qualidade total na produção. No início de seu livro, intitulado "Qualidade: a revolução da administração", Deming apontou que, tradicionalmente, se acreditava que qualidade e produtividade eram incompatíveis entre si, porque a busca por qualidade reduziria a produtividade e vice-versa. Porém, na opinião desse autor, quanto melhor a qualidade, maior a produtividade, porque se evitaria o retrabalho e o desperdício de tempo. ${ }^{52}$ Quanto melhor a qualidade, os custos diminuem, porque haverá menos retrabalho, menos erros, menos atrasos, menos obstáculos e melhor uso do tempo, dos maquinários e dos insumos; portanto, haverá maior produtividade. Acerca do impacto dos custos de fabricação e de reparação de produtos defeituosos em uma fábrica, Deming expôs o seguinte:

Determinada fábrica estava tendo uma grande quantidade de produtos deficientes. Perguntei ao gerente: 'Quantas pessoas estão engajadas nesta linha para refazerem as falhas cometidas em operações precedentes?'. O gerente foi ao quadro-negro e foi anotando 3 pessoas aqui, 4 acolá, e assim por diante; no total, $21 \%$ da mão-de-obra da linha. Os defeitos não saem de graça. Alguém os produz e é pago para fazê-los. Supondo-se que custe o mesmo tanto para corrigir um defeito quanto custa para fazê-lo, conclui-se que $42 \%$ da folha de pagamento e encargos estavam sendo gastos para produzir e reparar produtos defeituosos. ${ }^{53}$

\footnotetext{
51 DRUCKER, Peter Ferdinand. Introdução à administração. Tradução de Carlos A. Malferrari. São Paulo: Thomson Pioneira, 1984. p. 31.

52 DEMING, W. Edwards. Qualidade: a revolução da administração. Tradução de Francis Henrik Aubert, Maria Esmene Comenale e Áurea Consenza Dal Bó. Rio de Janeiro: Marques-Saraiva, 1990. p. 2.

53 Id. Ibid., p. 8-9.
} 
Como síntese de suas ideias, Deming lançou os seus quatorze princípios de administração. Destacam-se alguns deles: ${ }^{54}$

- "Deixe de depender da inspeção para atingir a qualidade. Elimine a necessidade de inspeção em massa, introduzindo a qualidade no produto desde seu primeiro estágio”.

- "Melhore constantemente o sistema de produção e de prestação de serviços, de modo a melhorar a qualidade e a produtividade e, consequentemente, reduzir de forma sistemática os custos".

- "Elimine o medo, de tal forma que todos trabalhem de modo eficaz para a empresa”.

- "Elimine as barreiras entre os departamentos. As pessoas engajadas em pesquisas, projetos, vendas e produção devem trabalhar em equipe, de modo que prevejam problemas de produção e de utilização do produto ou serviço".

- "Elimine lemas, exortações e metas para a mão-de-obra que exijam nível zero de falhas e estabeleçam novos níveis de produtividade. Tais exortações apenas geram inimizades, visto que o grosso das causas da baixa qualidade e da baixa produtividade encontram-se no sistema, estando, portanto, fora do alcance dos trabalhadores".

- "Elimine o processo de administração por objetivos. Elimine o processo de administração por cifras, por objetivos numéricos. Substitua-os pela administração por processos através do exemplo dos líderes".

- "Engaje todos da empresa no processo de realizar a transformação. A transformação é da competência de todo mundo”.

Porém, tornou-se mais conhecido o denominado "Sistema Toyota de Produção", desenvolvido a partir da constatação da inaplicabilidade do modelo de Ford na indústria japonesa, pelo fato de que não era possível a um país derrotado na guerra, sem recursos naturais, com pequeno mercado consumidor, produzir em larga escala, como se fazia nos Estados Unidos, nem impor um produto perante o mercado, por meio da fabricação de um único modelo. ${ }^{55}$ Partindo do princípio de que a produção

54 DEMING, W. Edwards. Qualidade: a revolução da administração. Tradução de Francis Henrik Aubert, Maria Esmene Comenale e Áurea Consenza Dal Bó. Rio de Janeiro: Marques-Saraiva, 1990. p. 18-19.

55 OHNO, Taiichi. O sistema Toyota de produção. Além da produção em larga escala. Porto Alegre: Bookman, 1997. p. 34-35. 
não deveria ser realizada como se fazia tradicionalmente na rizicultura, em que se estoca o excedente para enfrentamento dos períodos de escassez, e baseando-se no sistema de funcionamento dos supermercados dos Estados Unidos, ${ }^{56} \mathrm{em}$ que os consumidores se dirigem ao estabelecimento para adquirir o que precisam na quantidade exata, fazendose a reposição dos produtos nas prateleiras na medida em que são vendidos, o "Sistema Toyota de Produção" desenvolveu a ideia de diversificação dos produtos, bem como a releitura da cultura do combate ao desperdício, tendo como ponto máximo o "just-intime”, segundo o qual “(...) as partes corretas necessárias à montagem alcançam a linha de montagem no momento em que são necessários e somente na quantidade necessária". ${ }^{57}$ Dessa maneira, não se deveriam produzir peças ou produtos em grande quantidade para que fiquem estocados, aguardando consumidores para adquiri-los. Mais especificamente, busca-se a eliminação dos seguintes desperdícios: ${ }^{58}$

a) desperdício de superprodução;

b) desperdício de tempo disponível (espera);

c) desperdício em transporte;

d) desperdício do processamento em si;

e) desperdício de estoque disponível;

f) desperdício de movimento;

g) desperdício de produzir produtos defeituosos.

Segundo Taiichi Ohno, que implantou o "Sistema Toyota de Produção", o maior dos desperdícios é o excesso de estoques, porque se armazenou o que não seria consumido. Outro desperdício é o trabalho sem valor agregado, como o de caminhar para apanhar peças, abrir caixas, apertar botões, entre outros movimentos..$^{59}$

O segundo ponto do "Sistema Toyota de Produção" é a automação dos procedimentos, que consiste na colocação de dispositivos nas máquinas que as desligam quando se detecta automaticamente que o produto sairá defeituoso, exigindo-se a intervenção humana apenas para corrigir o funcionamento das mesmas. ${ }^{60}$ Há ainda um terceiro ponto, que é o do aprimoramento dos procedimentos de trabalho, que não podem apenas ser elaborados prévia e abstratamente, mas precisam ser testados e revisados na prática, além de serem escritos de forma clara, para que qualquer pessoa possa compreendê-

\footnotetext{
56 OHNO, Taiichi. O sistema Toyota de produção. Além da produção em larga escala. Porto Alegre: Bookman, 1997. p. 44-45.

57 Id. Ibid., p. 26.

58 Id. Ibid., p. 39.

59 Id. Ibid., p. 74.

60 Id. Ibid., p. 28.
} 
los de imediato. ${ }^{61}$ Todos aqueles que estiverem envolvidos na produção, devem informar aos demais todas as ocorrências das situações-problemas da produção, para sua correção. No relato de Shigeo Shingo, que trabalhou com Taiichi Ohno:

Eliminamos o desperdício examinando os recursos
disponíveis, reagrupando máquinas, melhorando processos
de usinagem, instalando sistemas autônomos, melhorando
ferramentas, analisando métodos de transporte, e otimizando
a quantidade de materiais disponíveis para processamento.
A alta eficiência da produção também foi mantida pela
prevenção da ocorrência de produtos defeituosos, erros
operacionais, acidentes, e pela incorporação das idéias
dos trabalhadores. Tudo isso é possível por causa da
imperceptível folha de trabalho padrão. ${ }^{62}$

Também dentro do contexto do "Sistema Toyota de Produção", os processos de produção são aperfeiçoados quando se faz a distinção entre o fluxo do produto (processo) e o fluxo de trabalho (operação), pois seria equivocado analisá-los conjuntamente. ${ }^{63}$ Logo, ou se aperfeiçoam os produtos fabricados ou se aperfeiçoa a tecnologia de sua fabricação.

Além disso, existiriam dois tipos de inspeção: a inspeção "post-mortem", que distingue o produto bom do produto ruim, e a inspeção sucessiva, em que cada um que recebe o insumo dentro da linha de produção, já faz a revisão, para evitar que se descarte o produto como um todo por ter-se deixado que seguisse com o defeito até o final. ${ }^{64}$

\section{Um exercício: e se o Poder Judiciário fosse analisado como uma empresa?}

Nos dias atuais, a administração aplicada à produção tornou-se uma disciplina estruturada, a qual ainda segue os conceitos básicos desenvolvidos por Taylor, Ford, Fayol, Drucker, Deming, Ohno e Shingo, entre outros. Tornou-se, inclusive, um dos tipos de engenharias - a engenharia de produção, cujas disciplinas fundamentais são administração de empresas, gerenciamento de produção, automação, controle de qualidade, logística e modelagem de sistemas de produção. ${ }^{65}$

${ }_{61}$ OHNO, Taiichi. O sistema Toyota de produção. Além da produção em larga escala. Porto Alegre: Bookman, 1997. p. 40.

62 Id. Ibid., p. 41.

63 SHINGO, Shigeo. O sistema Toyota de produção: do ponto de vista da engenharia de produção. Tradução de Eduardo Schaan. 2. ed. Porto Alegre: Bookman, 1996. p. 37.

64 Id. Ibid., p. 48.

${ }_{65}$ UNIVERSIDADE DE SÃO PAULO. Sistema Júpiter. Escola Politécnica. Departamento de Engenharia de Produção. Disciplinas de graduação. Disponível em: < https://uspdigital.usp.br/jupiterweb/jupDisciplinaLi sta? codcg=3\&pfxdisval $=$ PRO\&tipo $=\mathrm{D}>$. 
Praticamente todos os objetos destinados à comercialização no mercado, e parte dos serviços prestados, foram realizados por causa da organização da produção por gerentes de operações. ${ }^{66}$ Sendo assim, a administração da produção concentra-se em quatro variáveis - volume, variedade, procura e visibilidade - para que os responsáveis possam estabelecer um quadro geral das atividades e definir o modo mais adequado para a realização das mesmas, obtendo-se o melhor resultado operacional possível.

Em relação à variável "volume", quanto maior a quantidade de produtos fabricados ou de serviços prestados, requer-se mais sistematização da produção e mais especialização se exigirá dos funcionários para dar conta do atendimento da demanda. No tocante à variável "variedade", quanto mais opções de produtos e de serviços se disponibilizarem aos clientes, mais flexibilidade se exigirá na realização dos mesmos, sob pena de se elevarem excessivamente os custos unitários de produção. Para a variável "procura" pelos produtos e serviços pelo mercado, quanto mais sazonal esta for, maior capacidade de antecipação e de flexibilidade a empresa deverá ter para administrar os picos de demanda, os períodos de ociosidade e os custos unitários de produção. Por fim, no que concerne à "visibilidade", quanto mais contato os clientes tiverem com a empresa, a tolerância de espera pelo produto ou serviço será cada vez mais limitada, a satisfação será definida pela percepção dos consumidores e faz-se necessária maior habilidade de contato com os clientes. ${ }^{67}$

Além da análise dessas quatro variáveis, a boa administração da produção adota princípios de desempenho na realização das atividades, porque as pessoas não compram produtos ou serviços, mas compram um conceito de produto ou de serviço. Em outras palavras, não adianta apenas fabricar produtos ou prestar serviços: estes precisam vir acompanhados de certas características. A primeira delas é a qualidade do produto ou do serviço. Consiste na realização correta dos procedimentos desde o início, conforme as especificações previstas para que os produtos sejam fabricados e os serviços sejam prestados com o menor custo possível e que o contato com os clientes seja o mais cortês possível. A segunda delas é a rapidez, para que os clientes esperem o mínimo de tempo possível para ter sua necessidade satisfeita. Há ainda a confiabilidade, que é a confirmação da expectativa gerada pela empresa em termos de satisfação dessas necessidades. Por exemplo, em uma empresa de transportes, a confiabilidade está na chegada e partida no horário, bem como no conforto do veículo. ${ }^{68}$

\footnotetext{
${ }_{66}$ SLACK, Nigel; CHAMBERS, Stuart; JOHNSTON, Robert. Administração da produção. 2. ed. São Paulo: Atlas, 2009. p. 29.

67 Id. Ibid., p. 54.

68 Id. Ibid., p. 71-74.
} 
Somando-se à análise das variáveis da produção e à observância dos critérios de qualidade, rapidez e confiabilidade, a administração da produção segue os tradicionais princípios da administração, entre os quais o estabelecimento das estratégias de produção, a análise das necessidades das pessoas, elaboração do projeto de produção voltada à definição da melhor maneira de satisfazer os consumidores, a avaliação dos recursos disponíveis para tanto, bem como a análise da melhor maneira de realizá-los em termos de divisão do trabalho, de arranjos físicos e do emprego de tecnologias, a avaliação dos riscos de alteração dos modos atuais de produção, a preparação prévia para a execução das atividades, o controle da capacidade de atendimento do mercado, além da prevenção e recuperação de falhas. Em relação a este último aspecto, as falhas podem ser provocadas por erros de projeto, produção mal organizada, materiais inadequados, acidentes, falta de informação, além das falhas causadas por clientes. ${ }^{69}$

Apresentada a síntese desses conceitos da administração da produção, um exercício interessante consiste em analisar o Poder Judiciário como se fosse uma empresa, para compará-lo com outras atividades e identificar com mais clareza os problemas existentes. Por ser a jurisdição um serviço público prestado pelo Estado, perde-se um pouco a capacidade de compreensão das dificuldades estruturais atinentes à sua realização.

Como é sabido, o Poder Judiciário é uma instituição cujo objetivo é a produção de decisões sobre conflitos. Detém o monopólio legal dessa atividade. Excepcionalmente e, nos últimos tempos, com maior frequência, a arbitragem, modo artesanal de produção de decisão jurídica, tem sido usada para a solução de conflitos de grande complexidade, nos quais há somente direitos disponíveis envolvidos.

Em termos de "volume" de produção e "procura" por produtos, a atividade jurisdicional tem que confeccionar, diária e constantemente, uma grande quantidade de decisões judiciais. A sistemática da produção, ou a base da "linha de produção" está organizada em pequenas células isoladas umas das outras, denominadas de Ofícios, sem comunicação ou compartilhamento de atividades entre elas para a economia de recursos humanos ou materiais. Todos os Ofícios, portanto, têm praticamente as mesmas características. As matérias-primas dessa linha de produção são as informações contidas nas petições - fatos e argumentos jurídicos sobre os conflitos existentes - fornecidas por advogados e órgãos do Ministério Público e armazenadas nos autos dos processos. Não há como rejeitar a qualidade das informações fornecidas, isto é, não há como os magistrados reclamarem da qualidade das petições entregues. Não há qualquer padronização: podem vir com muitas informações quando poucas informações são necessárias ou vice-versa, em razão da maior ou menor capacidade de comunicação por escrito dos solicitantes.

${ }_{69}$ SLACK, Nigel; CHAMBERS, Stuart; JOHNSTON, Robert. Administração da produção. 2. ed. São Paulo: Atlas, 2009. p. 628. 
Cada juiz é responsável pela confecção da decisão, desde o seu início até o final, com o recebimento das matérias-primas (inicial, contestação, réplica etc.), passando pela transformação dessas matérias-primas por meio da fase de instrução (produção de provas e realização de audiências), até o momento da conclusão do produto, que é a publicação da sentença judicial às partes e demais interessados. Cabe, ainda, realizar o atendimento, a qualquer hora, de todos os envolvidos e destinatários da produção judicial, que exigem a entrega imediata do produto ou o atendimento de uma necessidade em determinado momento. A "visibilidade" da atividade produtiva é bastante elevada, porque dela participam os advogados, órgãos do Ministério Público, e o público em geral.

Os critérios de qualidade da produção estão definidos na Constituição Federal sob a forma de garantias processuais, entre as quais a observância das regras de produção judiciária (devido processo legal) e esta é organizada, em termos de fluxograma, pelos Códigos Processuais. Ao lado destes, existe ainda um código procedimental, informal, aprendido pela tradição oral de uma pessoa a outra nos estágios profissionais acerca do funcionamento dos ofícios. Por exemplo, os procedimentos para desarquivamento de autos físicos, extração de cartas de sentença e formais de partilha. As alterações no fluxograma de trabalho ocorre em intervalos não inferiores a dois anos, quando se elaboram reformas processuais, baseadas na experiência empírica e intuitiva de quem tem a possibilidade de propor algum projeto de lei.

A elevada demanda pela prestação jurisdicional faz com que os juízes tenham que construir diversas decisões simultaneamente, dando-se um passo de cada vez, o que torna impossível prever quando cada um deles será concluído e entregue. A divisão do trabalho é simplesmente formal, porque tudo continua concentrado na pessoa do magistrado, ainda que conte com auxiliares. Cada produto realizado tem padronização formal, porque se impõe apenas a mesma estrutura (relatório, fundamentos de fato e de direito, dispositivo). Em seu conteúdo, não existe uma padronização, mas uma normalização, decorrente da própria norma jurídica. Devido à liberdade do magistrado para decidir o conflito, desde que seu convencimento seja motivado, pode ocorrer com frequência a produção de decisões divergentes, conforme o entendimento, ideologia, maior ou menor conhecimento, experiência e preparo de quem a produziu. Embora sejam produtos da mesma organização, ou, sob a mesma marca, cada produto, portanto, terá, ao final, suas próprias características e qualidades. Nesse sentido, a "flexibilidade" da produção é motivada por quem criou a decisão judicial, e não por quem a requereu.

Há uma peculiaridade no momento da entrega do produto judicial: quando estiver disponibilizado às partes, este será revisado a posteriori por outros magistrados, podendo ser parcial ou totalmente refeito com a elaboração de um novo produto, denominado de acórdão. Parte considerável dos produtos judiciais costuma ser submetido a uma, duas ou três revisões completas, antes de ser definitivamente entregue 
aos interessados. Na prática, produzem-se, desnecessariamente, dois ou mais produtos iguais quando a sentença é confirmada pelo tribunal. Quando se entende que o produto é malfeito, este é parcial ou totalmente reconstruído. Tanto num caso quanto noutro, todo o trabalho realizado na elaboração da sentença é perdido com a elaboração do acórdão. Somente em caso de nulidade processual é que se corrigem erros, na acepção estrita do termo. O próprio sistema é estruturado para isso, porque obriga o advogado a pedir o refazimento do produto, quando este é desfavorável ao interesse da parte perdedora, mesmo que não tenha razão, sob pena de incorrer-se em potencial responsabilidade pela perda de uma chance.

O sistema recursal, que deveria ser usado apenas para corrigir erros, é também usado como meio de normalização das decisões, quando esta característica de uniformidade deveria estar presente desde o início. Todavia, os tribunais têm organização de trabalho similar à das instâncias inferiores, porque cada turma ou câmara está organizada como uma célula de produção individual. Portanto, os mesmos problemas se repetem, ou até mesmo se agravam nessas instâncias superiores. O controle de qualidade torna-se mais sobrecarregado que a linha de produção, porque cumula não apenas as funções corretivas, mas também avoca para si a própria responsabilidade pela produção. Também divergências de decisão costumam ocorrer dentro da própria turma ou câmara por nem sempre ser possível ter o controle do que se decidiu em casos similares por causa do excesso de recursos.

Considerando-se a decisão judicial como um produto, a fixação de seu preço é distinta da fixação do preço de outro produto qualquer. Enquanto nos demais casos o preço é a soma dos custos de produção mais o lucro, o preço da decisão judicial não é definido em termos de custos reais, por ser fixado em percentuais do valor da causa, como se aquelas de alto valor fossem mais complexas de resolver do que causas de pequeno valor. Não se sabe ao certo quanto custa, no caso concreto, uma ação de alimentos, uma ação de resolução contratual ou uma ação de indenização por danos morais. Pelo fato de o Poder Judiciário não ter fins lucrativos, o preço da decisão judicial inclui os custos administrativos - compra de materiais, estocagem, conservação, manutenção, segurança e limpeza - e a somatória do tempo de trabalho com valor agregado de magistrados e demais funcionários, que engloba os custos de processamento das informações contidas nas petições e os custos para que se tenha tranquilidade para redigir sentenças e acórdãos sem erros, para evitar que o trabalho seja perdido com a interposição de recursos. Pelo desconhecimento do custo de cada um desses componentes, é difícil saber com precisão o valor pelos serviços incorporados em cada decisão judicial para que se possa fazer melhor gerenciamento financeiro da atividade em um tribunal.

Se, em uma empresa qualquer, problemas simples são resolvidos pelos órgãos inferiores e graves problemas são imediatamente levados ao conhecimento dos 
órgãos diretores, isso não ocorre no Poder Judiciário. Devido à hierarquia das instâncias julgadoras, quase todos os problemas, tanto os simples quanto os complexos, são recebidos e resolvidos pelas instâncias inferiores e levam-se anos para que as instâncias superiores tomem conhecimento dos fatos e deem a palavra final ou as diretrizes de produção de novas decisões judiciais, por meio da jurisprudência ou de súmulas, vinculantes ou não. Enquanto isso não ocorre, o sistema fica instável, gerando produtos díspares entre si, o que ensejará trabalho redobrado com a revisão dos mesmos pelos tribunais, por meio dos recursos apresentados, para que a decisão esteja de acordo com o entendimento dominante.

Por fim, não há planejamento estratégico - ao menos não é divulgado - da maneira como se enfrentará a demanda por solução de conflitos daqui a cinco ou dez anos, ou qual a tendência da demanda por prestação jurisdicional em igual período, para, ao menos, os tribunais se organizarem para um atendimento mais eficiente da população.

Do ponto de vista da administração, observa-se, portanto, que ainda não foram incorporadas à atividade estatal de solução de conflitos os princípios estabelecidos no século XVIII, como o da divisão do trabalho preconizada por Adam Smith, bem como aqueles do início do século XX, entre os quais os de Taylor em termos de combate à fadiga e análise dos movimentos na execução das tarefas; os de Ford, de estandardização para a produção em massa em uma sociedade de massas; e o de Deming, Ohno e Shingo, na busca da qualidade total em cada etapa da produção para evitar o desperdício de tempo e de recursos naturais. Ao contrário, o Poder Judiciário é burocrático, porque usa o modelo de dominação racional, descrito por Max Weber. Como este autor destacou, a burocracia mantém-se por si mesma, sendo muito difícil provocar mudanças significativas. Nenhuma reforma processual surte efeitos, porque o próprio sistema reage aos efeitos da lei, mantendo-se tudo como antes. Basta observar que houve diversas reformas de direito processual no Brasil e muito pouco melhorou em termos práticos.

Ainda que se tenha disseminada a ideia de instrumentalidade do processo e seus escopos social, político e jurídico, que é, com efeito, a definição dos objetivos do Poder Judiciário enquanto instituição social, usa-se, de forma distorcida, a administração por objetivos de Drucker, estabelecendo-se metas de produtividade para que os magistrados, desembargadores e ministros aumentem suas produtividades sem prévia alteração das determinantes estruturais do sistema. Vale trazer a crítica de Deming à aplicação equivocada da administração por objetivos ao tratar dos efeitos da pressão sobre os funcionários:

Supõe-se, comumente, que a qualidade e a produtividade podem ser atingidas promovendo-se um arrocho geral, e instalando-se novos aparelhos e máquinas. Um livro que saiu recentemente explica como 'motivar seu pessoal para 
trabalhar a todo vapor!'. Chicoteie o cavalo, e ele correrá mais depressa - por algum tempo. ${ }^{70}$

Logo, não precisa ser formado em administração ou em economia para saber que já teria ido à falência uma empresa da qual se exige qualidade, entrega com rapidez e confiabilidade em termos de imparcialidade dos julgadores, mas que trabalha com grande volume de produção sem que se faça divisão do trabalho, nem se conhecem exatamente os custos unitários de produção, os magistrados e funcionários são submetidos à situação constante de fadiga pelo excesso de informações para serem processadas, as matérias-primas não são uniformes, os produtos entregues também não o são, aumentando seus custos unitários, além de gerar excessivo retrabalho provocado pela inspeção e revisão por meio dos recursos, com a irritante demora na entrega das decisões finais e insatisfação generalizada dos consumidores, devido à elevada visibilidade da atividade perante a sociedade. Por ser um monopólio legal do poder político, a atividade do Poder Judiciário produz os mesmos efeitos deletérios de um monopólio qualquer: entrega-se o mínimo de produtos possíveis aos consumidores, cobra-se caro por eles pela oferta menor e não importa o tempo que leva para ser produzido, porque não há alternativas de produtos, porque, até o presente momento, não se desenvolveram outros mecanismos de heterocomposição de conflitos que não sejam a decisão judicial e a arbitragem.

\section{Sugestões para um futuro Código de Processo Civil}

As sugestões que serão apresentadas concentram-se no direito processual civil, porque este ramo é aquele que mais se desenvolveu do ponto de vista científico no Brasil, e que serve de base para outros ramos do direito processual, como os processos penal e trabalhista. Também se aproveita o período de mudança de Código, momento em que, naturalmente, a comunidade jurídica dá maior atenção às mudanças e promove debates sobre a matéria com maior frequência.

O direito processual já oferece todos os requisitos de qualidade e de confiabilidade de uma decisão judicial. São, no caso, as garantias processuais, historicamente conquistadas, que funcionam como constantes do algoritmo da produção. Em outras palavras, toda decisão deve respeitar o devido processo legal, o contraditório, a ampla defesa, a igualdade de tratamento, a inadmissibilidade de provas obtidas por meios ilícitos, a publicidade dos atos e motivação das decisões. Além disso, os objetivos de um

70 DEMING, W. Edwards. Qualidade: a revolução da administração. Tradução de Francis Henrik Aubert, Maria Esmene Comenale e Áurea Consenza Dal Bó. Rio de Janeiro: Marques-Saraiva, 1990. p. 17. 
sistema de solução de conflitos também devem ser o de produzir decisões justas no menor tempo possível.

Por já estarem definidos os requisitos de qualidade e de confiabilidade de uma decisão judicial, existem duas possibilidades para a melhoria desse produto: ou se consegue aperfeiçoá-lo, desenvolvendo-se um instituto jurídico que possa substituir a sentença judicial, o que não parece ser possível, ou se aprimoram os procedimentos para a sua produção, o que é factível. Dessa maneira, é preciso fazer com que os procedimentos de trabalho possam ser eficazes em um contexto de grande volume de trabalho, no qual a procura por decisões é constante e com tendência ao aumento com o passar dos anos. A visibilidade é elevada pelos destinatários devido à proximidade do público na realização da atividade judiciária.

Dessa maneira, é imprescindível o combate ao desperdício de tempo, dinheiro em termos procedimentais, além do desperdício gerado por defeitos, que ensejarão recursos aos tribunais. Para isso, certos aspectos do processo poderiam ser aprimorados pela aplicação dos princípios da administração da produção.

a) Aprimoramento das operações (Workflow)

Deve-se reconhecer, inicialmente, que não há mais como manter um sistema de produção artesanal para o atendimento de uma sociedade de massas, que leva o Brasil a ter cerca de cem milhões de processos em andamento. Não há como deixar de levar em conta que a atividade do magistrado é a leitura e a escrita, que provocam fadiga. $\mathrm{O}$ juiz é um ser humano, sujeito a variações de rendimento provocadas por seus estados físico, mental e emocional. Ninguém é um computador de alta capacidade de processamento de dados e que não se cansa ao ler e escrever sem parar. $\mathrm{O}$ excesso de informações pode até mesmo levar à paralisia da atividade cognitiva.

Com seres humanos trabalhando sob essas condições, a própria organização do trabalho é fonte de erros, porque a capacidade de intelecção fica comprometida pela própria estrutura do sistema. Afinal, uma situação é o juiz ser falível; outra é o próprio sistema potencializar essa falibilidade. Na prática, a tendência é que a fadiga seja evitada pela redução da quantidade de decisões produzidas, tornando muito lenta a entrega das mesmas, prejudicando a variável "visibilidade" da atividade perante a sociedade, gerando, naturalmente, críticas e insatisfações. Deve-se considerar que toda essa insatisfação se retroalimenta, causando desmotivação aos magistrados e serventuários da justiça pela percepção de que todo o esforço empreendido por eles para que se consiga produzir o maior número de decisões judiciais no menor tempo possível, nem sempre será bem compreendido por advogados e pela população em geral.

A adoção do processo eletrônico é evidência de que maior efetividade da atividade judiciária não acontecerá sem que alterações profundas no fluxo de trabalho 
sejam implantadas. Este apenas modificou o registro dos atos processuais, de suporte mecânico de papel para suporte virtual, sem que provocasse significativas reduções de tempo para a entrega da decisão judicial às partes, porque, devido à sobrecarga do sistema, sabe-se que um desembargador recebe, em média, oitenta novas apelações em suporte virtual por semana para julgamento. Considerando-se que a jornada de trabalho de uma pessoa no Brasil é de, no máximo, quarenta e quatro horas semanais, este terá trinta minutos para ler os autos na tela de um computador, redigir seu voto, discutir o caso na sessão de julgamento e ouvir eventuais sustentações orais.

Portanto, a primeira sugestão para o aumento da produtividade e redução do tempo de entrega da decisão judicial é a implantação radical da divisão do trabalho, levando-se em conta a integração das atividades, para que não seja composta de atos meramente mecânicos. Tome-se como exemplo quatro juízes em um fórum e cada um deles é responsável por seu Ofício. Pela análise da rotina de trabalho de cada um deles, observase que pode ser concentrada em quatro ações: a) leitura de petições; b) atendimento ao público e prática de atos ordinatórios; c) realização da instrução processual; d) redação da sentença. Considerando que cada juiz proferirá " $x$ " sentenças por mês, quatro juízes proferirão quatro vezes essa quantidade.

Imagine-se agora a aplicação da divisão do trabalho entre esses mesmos quatro juízes, de modo que um deles tivesse apenas que ler petições iniciais, contestações e réplicas para identificar qual será o encaminhamento do processo - extinção sem resolução do mérito, verificação de pressupostos processuais, concessão de liminares; o segundo juiz somente se preocupasse em atender ao público e administrar os andamentos processuais, praticando todos os atos ordinatórios; o terceiro juiz ficasse encarregado apenas por realizar audiências e o quarto juiz fosse responsável por proferir sentenças, sem ser interrompido por ninguém, nem que tivesse que se preocupar com o atendimento de advogados ou com a realização de audiências. Muito provavelmente, a produção desses quatro juízes seria superior ao quádruplo da produção individual de cada um deles. Ademais, se poderia produzir um "checklist" para que se diminuam erros procedimentais e o juiz revisaria o próprio trabalho antes de passá-lo ao colega. Inclusive, nada obstaria o rodízio mensal entre eles, para que todos tivessem as mesmas oportunidades de trabalho dentro do fluxograma de produção.

A segunda sugestão está relacionada à quantidade de informações das petições. Devem-se louvar os magistrados e serventuários da justiça que, mesmo diante dessas adversidades, conseguem processar individualmente essa quantidade teratológica de informações contidas nos autos dos processos. Em um sistema ideal, em que o julgador somente tivesse que se preocupar com a resolução de um único caso, o oferecimento do maior número de argumentos possível seria louvável. Mas, num sistema estruturalmente saturado, esse fato impede o conhecimento das causas com rapidez. Portanto, toda 
petição deveria ter, no máximo, dez páginas. Caso se pretenda escrever mais, dever-seia cobrar uma taxa judiciária pelo acréscimo dos serviços, por implicar maiores custos de processamento de informações. Dessa forma, não se negaria o direito da parte de argumentar o que bem entender, mas se estimularia que apresentasse suas razões com mais objetividade. Inclusive daria mais transparência ao processo, ao permitir que maior número de pessoas pudesse compreender o objeto da disputa. Os advogados, que também fazem parte da "linha de produção judiciária" com suas petições e participação na fase de instrução processual, podem e devem igualmente concorrer para a boa administração da Justiça.

A terceira sugestão é a de que o Código de Processo Civil deve ser de fácil leitura, servindo, ao menos em termos procedimentais, como um "manual de instruções" a todos aqueles que trabalham com o Poder Judiciário. Como existe um hiato entre a concepção apriorística do procedimento e a sua execução prática, dever-se-ia criar um sistema de recolhimento de informações sobre o desempenho da organização do trabalho, a fim de que os juízes, desembargadores e ministros pudessem comunicar as falhas sistêmicas com mais rapidez e sugerir o aperfeiçoamento das mesmas. Dessa maneira, todos os atos ordinatórios inúteis, identificados na prática, seriam eliminados com mais facilidade. Felizmente, há um caso interessante dessa simplificação no novo Código de Processo Civil. Trata-se do pedido de citação como requisito da petição inicial. Ora, se uma das garantias do processo civil democrático é o contraditório e, obrigatoriamente, a outra parte precisa ser chamada ao processo para apresentação de suas razões, ainda que não queira comparecer, o requerimento de citação do réu como requisito da petição inicial é uma contradição em termos, pois não se poderia ter processo - entendido como relação jurídica - sem que o réu não tivesse sido citado. Muito tempo se perdeu porque alguém se esqueceu dessa formalidade. Não só isso: se o advogado incorresse nesse erro, o juiz não tinha a obrigação de apontá-lo com clareza: apenas ordenava a emenda da petição sob pena de indeferimento. Não parece ser eficiente exigir que quem errou, descubra o erro sozinho, em vez de indicar-se imediatamente e com clareza o que precisa ser consertado. Entretanto, poder-se-ia ter feito o mesmo com a exigência de pedido formal de produção de provas, que resulta na aposição da frase de estilo "Protesta e requer provar o alegado por todos os meios de prova admitidos em direito". Evidentemente, se uma das garantias constitucionais processuais é a ampla defesa, excetuando-se as provas obtidas por meios ilícitos, é ilógico imaginar um processo em que se roga ao Estado-juiz o beneplácito de poder provar o alegado. 
b) Por uma nova finalidade dos tribunais. Os custos pela inexecução das decisões judiciais.

Considerando que um dos princípios fundamentais da administração da produção é a fabricação com qualidade desde o início para evitar retrabalho e perda de tempo e de dinheiro, o ideal é que a quantidade de recursos submetidos aos tribunais seja a menor possível. Recursos provocados por erros deveriam ser excepcionais, porque a regra deveria ser o acerto da decisão judicial desde o início de sua elaboração, devendo o procedimento ser constantemente aperfeiçoado para que cada vez mais prevaleçam os acertos em vez dos erros.

Dessa forma, torna-se necessário que se analisem as causas dos recursos: se provêm de erros humanos sobre a interpretação dos fatos e do direito, ou se decorrem de divergências de interpretação do direito ou, ainda, se é a mera insatisfação pela perda da causa.

$\mathrm{Na}$ primeira hipótese, poder-se-iam manter grupos de trabalho para identificar em que situações ocorrem diversos erros procedimentais com mais frequência, para que estes sejam prontamente corrigidos mediante alterações legislativas.

$\mathrm{Na}$ segunda hipótese, em que há divergências de entendimentos e os recursos servem para promover a normalização das decisões, é imprescindível que a maioria absoluta delas já fosse uniforme desde o início, para que sejam atendidos os princípios de qualidade, rapidez e confiabilidade.

Seria importante que se obtivesse com rapidez a orientação para julgamento do problema levado ao conhecimento do Poder Judiciário, para ser adotada pelos magistrados em todas as situações similares ou casos repetitivos. A título de comparação, as tomadas de decisões em uma empresa são em níveis: diretoria, gerência, chefia etc. Não faz sentido que todo problema tivesse que ser resolvido obrigatoriamente pela chefia para que se recorra à gerência e, por fim, à diretoria. Nesse percurso, muito tempo seria desperdiçado.

Uma possibilidade seria a de que os casos fossem julgados imediatamente de acordo com sua complexidade, relevância social e urgência na definição do entendimento acerca da matéria. Por exemplo, quando recebesse a primeira lide sobre determinado assunto, o juiz avaliaria se este problema tem repercussão local, estadual ou nacional. Se o caso tiver repercussão local, o juiz resolve; se tiver repercussão estadual, que já seja julgado pelo tribunal para que se produza a orientação para os futuros casos; se tiver repercussão nacional, que já seja julgado pelos tribunais superiores com a mesma finalidade. Tanto em um como em outro caso, poder-se-ia elaborar com a máxima rapidez a súmula para as demais decisões futuras, a ser editada, portanto, quando aparecerem os primeiros casos e não como espécie de síntese conclusiva de milhares de processos após anos de julgamentos repetidos. Dessa forma, o Poder Judiciário já daria uma resposta 
rápida e uniforme à sociedade quando o problema aparecesse. Na medida em que novos casos fossem levados ao conhecimento dos juízes, estes já teriam a orientação para a tomada de decisão. A hierarquia judiciária poderia ser repensada de modo que os tribunais superiores fossem os administradores dos conflitos em geral e os juízes, os executores das soluções encontradas, assim como se tem uma visão panorâmica do espaço e outra visão da terra acerca do mesmo espaço. Esse sistema não implicaria o fim dos recursos. Ao contrário, estes são necessários para que ocorra o aperfeiçoamento da interpretação e aplicação do direito, mas se evitariam milhares de recursos que buscam apenas que a decisão desfavorável seja semelhante à da jurisprudência dominante. Ou, se o juiz perceber que está diante de um fato novo ou de uma interpretação mais adequada, que já faça a remessa ao tribunal competente, para que essa resposta seja a mais breve possível.

Quanto aos problemas recorrentes de direito material, os relatórios anuais do Conselho Nacional de Justiça já indicam quais são as principais causas levadas a julgamento no Brasil e, a partir disso, medidas imediatas poderiam ser tomadas para que esses fossem corrigidos por lei, em vez de continuarem a ser levados ao conhecimento do Poder Judiciário desnecessariamente, apenas para se confirmar o que já se sabe como justo.

Outra situação que poderia ter sido corrigida é a remessa necessária, feita a partir do pressuposto de que o Estado tem o interesse de ganhar a causa, mesmo quando não tem razão, embora essa ideia tenha sido relativizada nos últimos tempos e foi disciplinada com clareza no novo Código de Processo Civil. Trata-se de pressuposto equivocado o de que o juiz de primeiro grau é falível e, para evitar injustiças contra o Estado, a causa é devolvida a instância superior para novo julgamento. Do ponto de vista lógico, se existe essa desconfiança prévia no trabalho realizado pelo juiz, seria mais eficiente que o caso já fosse julgado diretamente pelo tribunal. Filosoficamente, é situação incompatível com o Estado Democrático de Direito, porque se o recurso é interposto mesmo quando o Estado não tem razão - o que não é incomum no Brasil - o maior prejudicado é o cidadão, que tem seu interesse sacrificado em nome da suposta proteção do bem-comum, que é também a do próprio prejudicado com esse recurso.

Por fim, o terceiro caso, em que os recursos são interpostos pela mera insatisfação da parte perdedora, ou para que se consiga protelar a eficácia da decisão judicial, e, ainda, nos casos relativos ao descumprimento de decisões transitadas em julgado, deve-se ter em vista a necessidade de definir com precisão os custos unitários de cada decisão refeita ou descumprida e repassá-los à parte rebelde, em vez de internalizálos no Poder Judiciário. Por exemplo, em caso de recurso em que se exija o reexame da causa sem que tenha ocorrido erro procedimental nem interpretação equivocada ou anormal da lei, deve-se cobrar com precisão a reexecução do serviço. Com mais razão se deve ter em vista o custo do descumprimento de cada decisão judicial e cobrá-los de forma 
detalhada da parte inadimplente. Em outras palavras, o quantum debeatur não pode ser apenas o crédito da parte vencedora, mas também o ressarcimento de todas as despesas diretas e indiretas do Poder Judiciário - que são os custos gerados pela sobrecarga de trabalho, que afetam a qualidade, rapidez e confiabilidade do sistema. Tendo em vista que metade das ações em tramitação no Brasil é de natureza executiva, o cálculo do valor de cada uma delas e a cobrança da parte descumpridora da decisão deveria ser de tal modo ajustados para que se mostre com clareza quanto esse acúmulo de serviço pelo descumprimento das decisões judiciais onera o sistema, bem como permitir a reflexão do que vale mais a pena: cumpri-la ou descumpri-la.

Ainda quanto aos custos, é sabido que existem os denominados "clientes do Judiciário", que são aquelas empresas que "terceirizam" seus Serviços de Atendimento ao Cliente para o Poder Judiciário, sobretudo nos Juizados Especiais, isentos de custas, que também geram uma grande quantidade de recursos. Se for possível avaliar a somatória dos custos unitários de todos os processos em que figuram, o Poder Judiciário poderia contabilizar o valor adequado por esses serviços prestados e apresentar a fatura detalhada relativa a todos eles, incluindo as despesas diretas e indiretas. A partir do momento em que se "enviar a conta para esses clientes", cujo preço inclua não apenas o custeio dos serviços prestados, mas também os custos gerados pela sobrecarga desnecessária de trabalho, as empresas teriam que rever seus custos e decidir o que é mais barato: lesar ou respeitar os consumidores.

\section{Conclusão}

Como se pode observar, a insatisfação com a eficiência e lentidão da atividade jurisdicional é antiga e tem sido objeto recorrente de reflexões doutrinárias, com o intuito de obter-se o contínuo aprimoramento do direito processual e do Poder Judiciário, de modo a oferecer à sociedade decisões de qualidade, com confiabilidade e, sobretudo, com rapidez. Esta é a intenção do legislador com a promulgação do novo Código de Processo Civil, do mesmo modo como foram as propostas das reformas processuais ocorridas durante a vigência do Código de 1973.

Práticas tradicionais ainda fazem parte da organização dos trabalhos judiciários, porque a preocupação natural dos juristas é com a aplicação do direito e não com a organização dos trabalhos, nem com a administração dos recursos humanos. Isso concorre para a lentidão da atividade, por não dar conta de atender à enorme demanda da população por uma prestação jurisdicional.

Por outro lado, atividades similares incorporaram preceitos da teoria da administração e, dessa maneira, têm sido realizadas com maior eficiência, atendendo-se cada vez mais as necessidades da sociedade. Nada obstaria que algumas dessas ideias, 
como o combate implacável ao desperdício de tempo, a divisão radical do trabalho, e eliminação de procedimentos desnecessários, pudessem ser implantadas na atividade jurisdicional, até mesmo porque muitas delas se referem a práticas extrajurídicas, mas que repercutem na esfera jurídica.

Espera-se que futuras modificações no processo civil ao menos levem em conta esses fatores, para que não haja frustração da comunidade jurídica, na hipótese de o novo Código de Processo Civil não conseguir atender plenamente as expectativas por decisões judiciais elaboradas no menor intervalo de tempo possível, sem perder, contudo, a distribuição da Justiça e o respeito às garantias processuais, que são verdadeiras conquistas do direito.

São Paulo, 21 de dezembro de 2015.

\section{Referências}

ALVES, José Carlos Moreira. Direito romano. 14. ed. rev., corrigida e aum. Rio de Janeiro: Forense, 2007.

BARBOSA, Rui. Oração aos moços. 8. ed. Rio de Janeiro: Ediouro, 1997.

CALAMANDREI, Piero. Eles, os juízes, vistos por nós, os advogados. Tradução de Ari dos Santos. Lisboa: Clássica, 1940.

CAPPELLETTI, Mauro; GARTH, Bryant. Acesso à justiça. Tradução e revisão de Ellen Gracie Northfleet. Porto Alegre: Fabris, 1988.

CHIAVENATO, Idalberto. Teoria geral da administração. Abordagens prescritivas e normativas da administração. 6. ed. rev. e atual., 13. tir. Rio de Janeiro: Elsevier, 2001. v. 1.

DEMING, W. Edwards. Qualidade: a revolução da administração. Tradução de Francis Henrik Aubert, Maria Esmene Comenale e Áurea Consenza Dal Bó. Rio de Janeiro: Marques-Saraiva, 1990.

DINAMARCO, Cândido Rangel. A instrumentalidade do processo. São Paulo: Revista dos Tribunais, 1987.

DRUCKER, Peter Ferdinand. Introdução à administração. Tradução de Carlos A. Malferrari. São Paulo: Thomson Pioneira, 1984.

. Prática da administração de empresas. Tradução de Carlos A. Malferrari. São Paulo: Thomson Pioneira, 1981.

FAYOL, Henri. Administração industrial e geral. Tradução de Irene de Bojano e Mário de Souza. 9. ed. São Paulo: Atlas, 1977. 
FORD, Henry. Os princípios da prosperidade. Tradução de Monteiro Lobato. 3. ed. São Paulo: Freitas Bastos, 1967.

GABBAY, Daniela Monteiro et al. Cândido Rangel Dinamarco e a instrumentalidade do processo (uma entrevista). Cadernos Direito GV. São Paulo: Direito GV, v. 7, n. 4, p. 1-41, jul. 2010.

HUBERMAN, Leo. História da riqueza do homem. Tradução de Valtensir Dutra. 21. ed. Rio de Janeiro: Guanabara-Koogan, 1986.

LASPRO, Oreste Nestor de Souza. Duplo grau de jurisdição no direito processual civil. São Paulo: Revista dos Tribunais, 1995.

LODI, João Bosco. Introdução à Obra de Peter F. Drucker. RAE-Revista de Administração de Empresas, São Paulo, v. 8, n. 29, p. 80-137, out./dez., 1968.

MANCUSO, Rodolfo de Camargo. A resolução dos conflitos e a função judicial no contemporâneo Estado de Direito. 2008. Tese (Professor Titular) - Faculdade de Direito, Universidade de São Paulo, São Paulo, 2008.

MARCATO, Antonio Carlos. Crise da justiça e influência dos precedentes judiciais no direito processual civil brasileiro. 2008. Tese (Professor Titular) - Faculdade de Direito, Universidade de São Paulo, São Paulo, 2008.

MAXIMIANO, Antonio Cesar Amaru. Introdução à administração. 7. ed. rev. e ampl. São Paulo: Atlas, 2008.

OHNO, Taiichi. O sistema Toyota de produção. Além da produção em larga escala. Porto Alegre: Bookman, 1997.

SHINGO, Shigeo. O sistema Toyota de produção: do ponto de vista da engenharia de produção. Tradução de Eduardo Schaan. 2. ed. Porto Alegre: Bookman, 1996.

SLACK, Nigel; CHAMBERS, Stuart; JOHNSTON, Robert. Administração da produção. 2. ed. São Paulo: Atlas, 2009.

SMITH, Adam. Investigação sobre a natureza e as causas da riqueza das nações. Tradução de Conceição Jardim Maria do Carmo Cary e Eduardo Lucio Nogueira. São Paulo: Abril Cultural, 1974. (Os Pensadores).

TAYLOR, Frederick Winslow. Princípios de administração científica. 7. ed. Tradução de Arlindo Vieira Ramos. São Paulo: Atlas, 1970.

TUCCI, José Rogério Cruz e; AZEVEDO, Luiz Carlos de. Lições de processo civil canônico: história e direito vigente. São Paulo: Revista dos Tribunais, 2001.

TUCCI, José Rogério Cruz e. Tempo e processo: uma análise empírica das repercussões do tempo na fenomenologia processual: civil e penal. São Paulo: Revista dos Tribunais, 1997. 
UNIVERSIDADE DE SÃO PAULO. Sistema Júpiter. Escola Politécnica. Departamento de Engenharia de Produção. Disciplinas de graduação. Disponível em: <https://uspdigital.usp.br/ jupiterweb/jupDisciplinaLista?codcg=3\&pfxdisval=PRO\&tipo=D $>$.

VELLOSO, Augusto Versiani. Textos de direito romano. Bello Horizonte: Imprensa Official de Minas, 1923.

WEBER, Max. Economía y sociedad: esbozo de sociología comprensiva. Tradução de José Medina Echavarria, Juan Roura Parella, Eugenio Imaz, Eduardo Garcia Maynes e José Ferrater Mora. Cidade do México: Fondo de Cultura Económica, 1992. 